\title{
Performance evaluation of the products of different drip irrigation companies
}

\author{
V. L. PAWAR AND V. D. PARADKAR
}

\section{Abstract}

The research was carried out at Puriya Park Farm, K. K. Wagh College of Agricultural Engineering and Technology, Nashik, in October 2014. The performance of drip products manufactured by different companies viz., Company A, Company B and Company $\mathrm{C}$ was evaluated. Two NPC emitters of $4 \mathrm{lph}$ and $8 \mathrm{lph}$ were tested at operating pressure ranging from 0.5 to $1.25 \mathrm{~kg} /$ $\mathrm{cm}^{2}$ and one PC emitter of $4 \mathrm{lph}$ discharge was tested at same operating pressure range. Also, the emission uniformity (EU) and co-efficient of uniformity (CU) of drip system was worked out. In 4 lph and 8 lph NPC drippers manufactured by Company A, discharge variation with respect to pressure was less as compare to standard discharge values of Company B and Company C. In 4 lph PC drippers manufactured by Company B, discharge variation with respect to pressure was very less as compared to standard discharge values of Company A and Company $\mathrm{C}$.

KEY WORDS : Drip, Performance evaluation

How to cite this Article : Pawar, V.L. and Paradkar, V. D. (2017). Performance evaluation of the products of different drip irrigation companies. Engg. \& Tech. in India, 8 (1\&2) : 58-64; DOI : 10.15740/HAS/ETI/8.1\&2/ 58-64. 